\title{
TINJAUAN PENAMBAHAN ADITIF MINERAL ABU TERBANG TERHADAP KETAHANAN BETON PADA LINGKUNGAN AGRESI SULFAT
}

\author{
Ernawati Sri Sunarsih \\ Program Studi Pendidikan Teknik Bangunan, FKIP, Universtas SebelasMaret \\ Jl. Ir. Sutami 36 A, Kentingan, Surakarta 57126 telp. (0271) 663375 \\ email : ernauns@yahoo.com
}

\begin{abstract}
The research aims to determine (1) the increase of compressive strength of concrete with addition of fly ash to be compared to normal concrete (2) the resistant of normal concrete and also concrete with fly ash mineral additive in 2\%, 5\% and 7\% sulphuric acid solutions, and (3) the resitant of concrete with fly ash mineral additive with the increase of concentration of sulphuric acid solution in comparing normal concrete.

The method employed in this research was experimental method, by preparing the test object constituting the concrete cylinder with $\varnothing 150 \mathrm{~mm}$ and $300 \mathrm{~mm}$ height for the compressive strength test. With the percentage of fly ash addition are $0 \%, 20 \%, 30 \%$ and $40 \%$ from requirement cement and qualities of designed concrete is 22,5 MPa. Amount of object test to the each condition is 4. To know concrete resistant in sulphate aggression environment, hence conducted by immersied of concrete in sulphuric acid solutions with concentration $2 \%, 5 \%$ and $7 \%$ during 30 days.

From the research, it can be found that: (1) the addition of fly ash into fresh concrete will improve compressive strength of concrete. At addition fly ash $20 \%$ from requirement cement, compressive strength of concrete increase $23,39 \%$. For the addition of fly ash $30 \%$ and $40 \%$, the increase of compressive strength concrete were $21,54 \%$ and $0,31 \%$. While in optimum percentage of fly ash addition is $23,46 \%$ (2) the immersied concrete in sulphuric acid solution result degradation compressive strength of concrete. At the same concentration of sulphuric acid solution, concrete with fly ash additive mineral have resistant which is better to be compared to normal concrete. This seen [at] percentage of compressive strength degradation of fly ash concrete which is smaller to be compared to normal concrete. Equally the percentage of compressive strength degradation inversely proportional with the percentage of fly ash addition (3) the increase of concentration of sulphuric acid solution will be result of aggression that happened at ever greater. If compared to normal concrete, concrete with fly ash in the reality more effective if used at high concentration of sulphuric acid solution. This matter can be seen from difference of percentage of compressive strength degradation ever greater at the height of concentration of sulphuric acid solution.
\end{abstract}

Keywords: compressive strength, fly ash, sulphuric acid 


\begin{abstract}
ABSTRAK
Penelitian ini bertujuan untuk mengetahui (1) peningkatan kuat desak beton dengan penambahan aditif mineral abu terbang dibandingkan dengan beton normal (2) ketahanan beton normal maupun beton dengan aditif mineral abu terbang dalam larutan asam sulfat $2 \%, 5 \%$ dan $7 \%$, dan (3) ketahanan beton dengan aditif mineral abu terbang dengan adanya peningkatan konsentrasi larutan asam sulfat di bandingkan beton normal.

Metode yang digunakan dalam penelitian ini adalah metode eksperimen, dengan membuat benda uji berupa silinder beton dengan $\varnothing 150 \mathrm{~mm}$ dan tinggi $300 \mathrm{~mm}$ untuk uji kuat tekan. Dengan persentase penambahan abu terbang 0\%, 20\%, 30\% dan $40 \%$ dari kebutuhan semen dan mutu beton rencana 22,5 MPa. Jumlah benda uji untuk masing-masing kondisi adalah 4 buah. Untuk mengetahui ketahanan beton dalam lingkungan agresi sulfat, maka dilakukan perendaman beton dalam larutan asam sulfat dengan konsentrasi $2 \%, 5 \%$ dan $7 \%$ selama 30 hari.

Dari hasil pengujian diketahui : (1) Penambahan abu terbang kedalam adukan beton akan meningkatkan kuat tekan beton. Pada penambahan abu terbang $20 \%$ dari berat semen kuat tekan beton naik sebesar 23,39\%. Untuk penambahan abu terbang $30 \%$ dan $40 \%$, peningkatan kuat tekan beton masing-masing adalah $21,54 \%$ dan $0,31 \%$. Sedangkan prosentase penambahan abu terbang yang optimum yaitu sebesar $23,46 \%$. Setelah tercapai nilai optimum, penambahan abu terbang ke dalam adukan beton mengakibatkan nilai kuat tekannya menurun, akan tetapi masih lebih tinggi dibandingkan dengan kuat tekan beton normal (2) Perendaman beton dalam larutan asam sulfat mengakibatkan penurunan kuat tekan beton. Pada konsentrasi larutan asam sulfat yang sama, beton dengan bahan aditif abu terbang mempunyai ketahanan yang lebih baik dibandingkan beton normal. Ini terlihat pada persentase penurunan kuat tekan beton abu terbang yang lebih kecil dibandingkan beton normal. Dengan kata lain prosentase penurunan kuat tekan beton berbanding terbalik dengan prosentase penambahan abu terbang (3) Peningkatan konsentrasi asam sulfat akan mengakibatkan agresi yang terjadi pada beton juga semakin besar. Apabila dibandingkan dengan beton normal, beton dengan bahan aditif abu terbang ternyata lebih efektif bila digunakan pada larutan asam sulfat konsentrasi tinggi. Hal ini dapat dilihat dari selisih prosentase penurunan kuat tekan beton yang semakin besar dengan meningkatnya konsentrasi larutan asam sulfat.
\end{abstract}

Kata kunci: kuat tekan beton, abu terbang, asam sulfat 
PENDAHULUAN

\section{Latar Belakang}

Perkembangan teknologi yang semakin pesat menuntut pula perkembangan dibidang sarana dan prasarana, khususnya struktur bangunan yang lebih awet dan murah. Beton sebagai material konstruksi bila dikerjakan dengan baik telah sejak lama dikenal sebagai bahan yang kuat dan awet. Namun, dalam perjalanan pembangunan struktur sipil juga dikenal faktor-faktor fisis, mekanik dan kimia yang dapat mengakibatkan terjadinya korosi dan degradasi material beton.

Bahan kimia agresif yang sering mengakibatkan penurunan sifat karakteristik pada beton bisa datang dari lingkungan luar yaitu garam sulfat, asam sulfat dan asamasam lainnya. Dari beberapa penelitian tentang beton yang berhubungan langsung dengan lingkungan sulfat, disebutkan bahwa kadar sulfat lebih dari $2 \%$ dalam tanah yang larut dalam air, digolongkan sebagai kadar gangguan sulfat yang berat.

Mekanisme yang terjadi akibat serangan sulfat terhadap beton terutama karena larutnya Kalsium Hidroksida, yang merupakan hasil proses hidrasi semen dengan air. Kenyataan lain bahwa serangan larutan sulfat terjadi lewat infiltrasi atau merembes kedalam beton lewat pori-pori beton. Kecepatan agresi sulfat tergantung dari jenis senyawa dimana sulfat timbul, konsentrasi sulfat, nilai $\mathrm{pH}$ tanah atau air tanah, permeabilitas (daya lulus air) serta retak beton.
Oleh karena itu, untuk meningkatkan ketahanan beton terhadap serangan sulfat yaitu dengan meminimalkan kandungan Kalsium Hidroksida dalam beton dan juga jumlah pori dalam beton. Salah satu cara yang ditempuh yaitu dengan penambahan aditif mineral abu terbang yang merupakan limbah pembakaran batubara. Abu terbang mengandung unsur-unsur silikat ( $\mathrm{SiO} 2)$ dan aluminat (Al2O3), dimana kedua unsur tersebut reaktif terhadap Kalsium Hidroksida $(\mathrm{Ca}(\mathrm{OH}) 2)$ yang terdapat pada beton. Selain itu dengan ukurannya yang relatif kecil, abu terbang juga bisa berfungsi sebagai filler sehingga dapat mengurangi pori-pori dalam beton.

\section{Rumusan Masalah}

1. Seberapa besar perbedaan kuat tekan beton dengan aditif mineral abu terbang dibandingkan beton normal.

2. Seberapa besar ketahanan beton normal maupun beton dengan aditif mineral abu terbang dalam larutan asam sulfat.

3. Seberapa besar ketahanan beton dengan aditif mineral abu terbang dibandingkan dengan beton normal dengan adanya peningkatan konsentrasi larutan asam sulfat.

\section{Landasan Teori}

\section{Abu Terbang (Fly Ash)}

Batubara sebagai bahan bakar banyak digunakan di PLTU. Kecenderungan dewasa ini akibat naiknya harga minyak diesel industri, maka banyak perusahaan yang 
beralih menggunakan batubara sebagai bahan bakar dalam menghasilkan steam (uap). Sisa hasil pembakaran dengan batubara menghasilkan abu yang disebut dengan fly ash dan bottom ash (5-10\%). Persentase abu (fly ash dan bottom ash) yang dihasilkan adalah fly ash (80-90\%) dan bottom ash (10$20 \%$ ) : [Sumber PJB Paiton]. Umumnya komposisi kimia fly ash yaitu : $\mathrm{SiO}_{2}$ : $52,00 \%, \mathrm{Al}_{2} \mathrm{O}_{3}: 31,86 \%, \mathrm{Fe}_{2} \mathrm{O}_{3}: 4,89 \%$, $\mathrm{CaO}: 2,68 \%, \mathrm{MgO}: 4,66 \%$. (Kementerian Negara Lingkungan Hidup, 2006)

Bahan bangunan abu terbang dapat digunakan sebagai bahan baik untuk pembuatan agregat buatan dalam campuran beton, bahan tambahan paving blok, mortar, batako, bahan tambah beton aspal, beton ringan dan sebagainya. Sebagai bahan tambah beton, abu terbang dinilai dapat meningkatkan kualitas beton dalam hal kekuatan, kekedapan air, ketahanan terhadap sulfat dan kemudahan dalam pengerjaan (workability) beton (Sofwan Hadi, 2000).

Penggunaan abu terbang juga dapat mengurangi penggunaan semen dan sekaligus sebagai bentuk pemanfaatan limbah yang akan membantu menjaga kelestarian lingkungan. Abu terbang sepertinya cukup baik untuk digunakan sebagai bahan ikat karena bahan penyusun utamanya adalah silikon dioksida ( $\mathrm{SiO} 2)$, alumunium (Al2O3) dan Ferrum oksida (Fe2O3). Oksida-oksida tersebut dapat bereaksi dengan kapur bebas yang dilepaskan semen ketika bereaksi dengan air. Clarence (1966: 24) menjelaskan dengan pemakaian abu terbang sebesar 20 $30 \%$ terhadap berat semen maka jumlah semen akan berkurang secara signifikan dan dapat menambah kuat tekan beton. Pengurangan jumlah semen akan menurunkan biaya material sehingga efisiensi dapat ditingkatkan.

Menurut standar SNI 03-6863-2002 (2002: 150) penggunaan abu terbang sebagai bahan tambah beton, baik untuk adukan maupun campuran beton harus memenuhi syarat-syarat seperti tabel 1 .

Tabel 1. Susunan kimia abu terbang

\begin{tabular}{|c|c|c|c|}
\hline No. & Uraian & $\begin{array}{c}\text { Kelas F } \\
(\%)\end{array}$ & $\begin{array}{c}\text { Kelas C } \\
(\%)\end{array}$ \\
\hline A. & $\begin{array}{l}\text { Susunan Kimia } \\
\text { 1. Silkon dioksida + alumunium oksida }+ \\
\text { besi oksida, min } \\
\text { 2. Sulfur trioksida, maks } \\
\text { 3. Kadar air, maks } \\
\text { 4. Hilang Pijar, maks } \\
\text { 5. Na2O, maks }\end{array}$ & $\begin{array}{l}70.00 \\
5.00 \\
3.00 \\
6.00 \\
1.50\end{array}$ & $\begin{array}{l}50.00 \\
5.00 \\
3.00 \\
6.00 \\
1.50\end{array}$ \\
\hline B. & $\begin{array}{l}\text { Sifat fisik } \\
\text { 1. Kehalusan sisa di atas ayakan } 4 \text { um, } \\
\text { maks } \\
\text { 2. Indeks keaktifan pozolan dengan PC I, } \\
\text { pada umur minimal } 28 \text { hari } \\
\text { 3. Air, maks } \\
\text { 4. Pengembangan dengan autoclave, maks }\end{array}$ & $\begin{array}{c}34.00 \\
75.00 \\
105.00 \\
0.80\end{array}$ & $\begin{array}{c}34.00 \\
75.00 \\
105.00 \\
0.80\end{array}$ \\
\hline
\end{tabular}

Tabel 2. Komposisi kimia abu terbang PT. Tjiwi Kimia Putra

\begin{tabular}{|lc|c|c|c|}
\hline \multicolumn{2}{|c|}{ Parameter } & Satuan & $\begin{array}{c}\text { Hasil Uji Abu } \\
\text { terbang }\end{array}$ & Metode pengujian \\
\hline Moisture & AR & $\%$ & 0.56 & Drying oven $105^{\circ} \mathrm{C}, 2$ hours \\
$\mathrm{LOI}$ & $\mathrm{DB}$ & $\%$ & 5.38 & combustion at $900^{\circ} \mathrm{C}$ \\
$\mathrm{Al}_{2} \mathrm{O}_{3}$ & $\mathrm{DB}$ & $\%$ & 28.48 & AAS \\
$\mathrm{SO}_{3}$ & $\mathrm{DB}$ & $\%$ & 0.45 & Gravimetric \\
$\mathrm{Fe}_{2} \mathrm{O}_{3}$ & $\mathrm{DB}$ & $\%$ & 8.28 & AAS \\
$\mathrm{CaO}^{2}$ & DB & $\%$ & 3.32 & AAS \\
$\mathrm{Na}_{2} \mathrm{O}$ & $\mathrm{DB}$ & $\%$ & 0.29 & AAS \\
$\mathrm{SiO}_{2}$ & $\mathrm{DB}$ & $\%$ & 48.31 & Gravimetric \\
\hline
\end{tabular}




\section{Beton Abu Terbang}

Suharwanto, 2000 menyatakan bahwa dalam proses hidrasi, air dalam campuran beton segar akan mengikat Dikalsium Silikat $\left(\mathrm{C}_{2} \mathrm{~S}\right)$ dan Trikalsium Silikat $\left(\mathrm{C}_{3} \mathrm{~S}\right)$ yang kemudian menjadi Kalsium Silikat hidrat gel $\left(3 \mathrm{CaO} .2 \mathrm{SiO}_{2} .3 \mathrm{H}_{2} \mathrm{O}\right.$ atau $\left.\mathrm{CSH}\right)$ dan membebaskan Kalsium Hidroksida $\left(\mathrm{Ca}(\mathrm{OH})_{2}\right)$. Tambahan abu terbang yang mengandung silica $\left(\mathrm{SiO}_{2}\right)$ akan bereaksi dengan $\mathrm{Ca}(\mathrm{OH})_{2}$ yang dibebaskan dari proses hidrasi dan akan membentuk CSH kembali, sehingga beton yang dibentuknya akan lebih padat dan kuat atau mutunya bertambah. Reaksi ini sering disebut reaksi sekunder dan reaksi ini berjalan lebih lambat dan berlaku lebih lama, sehingga mutu beton diatas umur 28 hari masih dapat meningkat.

X. J. Song, M. Marosszeky, M. Brungs, R. Munn, 2005 menyatakan bahwa: "Beton dengan geopolymer abu terbang yang direndam dalam larutan asam sulfat 10\% selama 4 minggu mengalami pengurangan berat yang jauh lebih rendah (sekitar 3\%) dibandingkan beton normal (sekitar 41\%). Dari kenyataan ini dapat disimpulkan bahwa beton dengan geopolymer abu terbang tahan terhadap serangan sulfat".

\section{Agresi Sulfat Pada Beton}

Pada beton yang kurang kedap/padat, $\mathrm{Ca}(\mathrm{OH})_{2}$ dari dalam beton akan keluar. Dan keluarnya $\mathrm{Ca}(\mathrm{OH})_{2}$ ini menambah pori-pori beton, sehingga beton mudah diserang oleh zat-zat kimia. (Aman Surbakti, 1995)
Murdock dan brook (1991), menyatakan bahwa : "dalam merancang sebuah campuran beton harus memperhatikan dua sifat beton keras (hardened concrete), yaitu kekuatan beton dan keawetan beton. Kekuatan beton sangat berhubungan erat dengan beban yang bekerja pada stuktur beton tersebut, sedangkan keawetan beton berhubungan erat dengan lingkungan di mana struktur beton tersebut dibuat. Beberapa penyebab kerusakan beton dapat di kelompokkan menjadi 3 kategori, yaitu fisik, mekanik dan kimia. Dan salah satu penyebab yang mempengaruhi keawetan beton adalah larutan asam sulfat.

Dalam proses agresi sulfat pada beton, terdapat bukti kenampakan perubahan warna keputihan pada beton. Agresi ini akan dibarengi dengan pengembangan yang tak begitu besar karena terlepasnya bagian ikatan dari beton akibat larutnya $\mathrm{Ca}(\mathrm{OH})_{2}$ dalam larutan sulfat. Ketika agresi berlangsung selain terjadi perubahan warna, juga terjadi retak, penggelembungan, yang mulai dari permukaan beton yang padat kemudian masuk lebih kedalam beton yang porous. Kecepatan agresi sulfat pada beton tergantung beberapa faktor, antara lain :

a. Jenis larutan sulfat. Larutan sulfat yang dapat merusak beton adalah larutan sulfat yang mudah larut. Hal ini berhubungan erat dengan cara pengrusakan yaitu dengan perembesan (infiltrasi).

b. Suhu dan tekanan larutan. 
c. Konsentrasi. Semakin tinggi konsentrasi sulfat dalam larutannya, maka semakin serius agresi yang ditimbulkan. Berat tidaknya agresi ini bertambah bilamana aliran air yang mengandung sulfat mengadakan dan menjadikan garamnya lekat pada beton.

d. Permeabilitas (daya meluluskan air) beton. Beton yang kedap air hanya mengalami agresi pada permukaannya dan oleh karena itu daya merusaknya lambat. Sedangkan beton yang tidak kedap air, terutama bila salah satu sisinya berhubungan dengan tanah basah yang mengandung sulfat, sedang sisi lainnya terbuka bebas sedemikian hingga penguapan dapat berlangsung atau bilamana mengalami salah satu sisi tekanan air, akan mengalami agresi keseluruh tebal serta mengakibatkan suatu pengembangan total dan seluruhnya akan mengalami perpecahan. (Murdock dan Brook, 1991).

Dalam penelitian ini pelaksanaan perendaman diambil 30 hari. Hal ini merujuk pada hasil penelitian dari Murdock, L.J. dan
Brook, K.M. tentang kecepatan pengrusakan beton oleh sulfat. Untuk kasus kandungan $\mathrm{C}_{3} \mathrm{~A}$ semen antara 3\% sampai $9 \%$, banyak semen $223 \mathrm{~kg} / \mathrm{m}^{3}$ dan $307 \mathrm{~kg} / \mathrm{m}^{3}$ beton dan kondisi sodium sulfat $10 \%$ terjadi kecepatan pengrusakan antara $15 \%$ sampai $100 \%$ pertahun.

\section{METODE PENELITIAN}

Pelaksanaan penelitian dilakukan didua tempat, yaitu untuk uji bahan di laksanakan di Laboratorium Bahan Fakultas Teknik UNS, sedangkan untuk uji kuat tekan benda uji di Laboratorium Beton PTB FKIP UNS.

Benda uji berbentuk silinder dengan diameter $15 \mathrm{~cm}$ dan tinggi $30 \mathrm{~cm}$. Jumlah sampel dalam penelitian ini adalah :

1. Beton normal 16 buah sampel.

2. Beton fly ash dengan variasi prosentasenya $20 \%, 30 \%$ dan $40 \%$ dari berat semen masing-masing 16 buah, sehingga totalnya 48 buah sampel

Secara skematis tahap-tahap penelitian ini dapat dilihat pada bagan alir tahapan penelitian pada gambar. 


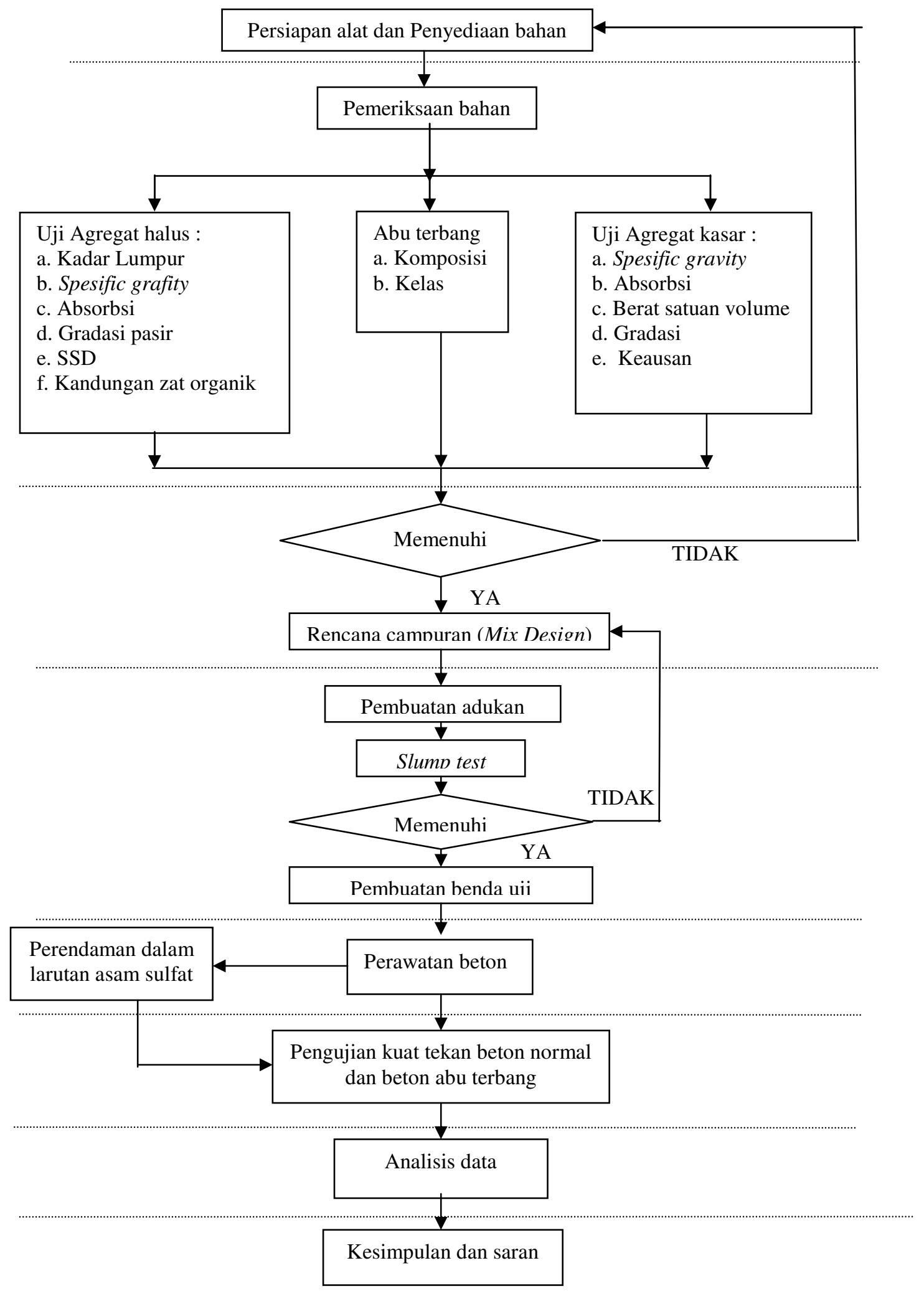

Gambart 1. Bagan alir tahap-tahap penelitian 


\section{HASIL DAN PEMBAHASAN}

\section{Perbedaan Kuat Tekan Beton Normal} dengan Beton Abu Terbang

Dari hasil penelitian di laboratorium terlihat bahwa penambahan bahan aditif abu terbang kedalam campuran adukan beton dapat meningkatkan kuat tekan beton. Dari hasil penelitian terlihat bahwa prosentase peningkatan kuat tekan beton tertinggi pada penambahan abu terbang $20 \%$ dari berat semen yaitu sebesar $23,39 \%$. Untuk penambahan abu terbang sebesar 30\% dan $40 \%$, besarnya peningkatan kuat tekan masing-masing adalah $21,54 \%$ dan $0,31 \%$.

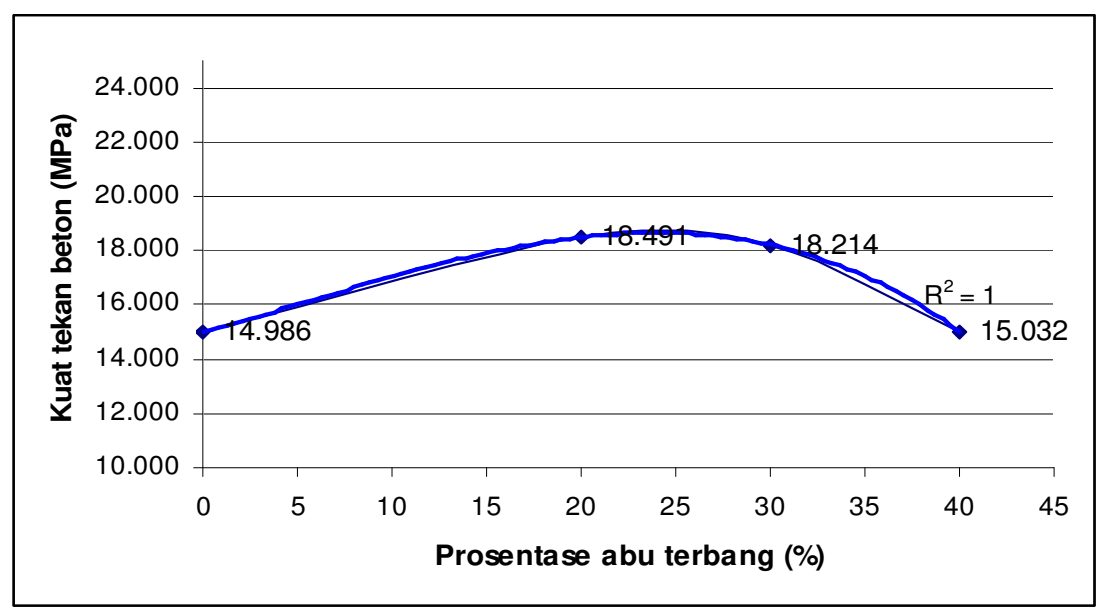

Gambar 1. Grafik hubungan prosentase abu terbang dengan kuat tekan beton.

Dari grafik dapat diketahui nilai optimum penambahan abu terbang kedalam adukan beton agar diperoleh kuat tekan beton maksimum yaitu sebesar $23,46 \%$.

Terlihat bahwa setelah tercapai nilai optimum, penambahan abu terbang ke dalam adukan beton mengakibatkan nilai kuat tekannya menurun, akan tetapi masih lebih tinggi dibandingkan dengan beton normal. Hal ini sesuai dengan pendapat Ratmaya Urip (2002) yang mensyaratkan penggunaan abu terbang sebagai bahan bangunan adalah 20\%$30 \%$.

Kenaikan kuat tekan beton pada penambahan abu terbang terjadi karena secara kimiawi abu terbang bersifat hidrolik yang bereaksi mengikat kapur bebas atau kalsium hidroksida $(\mathrm{Ca}(\mathrm{OH}) 2)$ yang dilepaskan semen saat proses hidrasi. Reaksi kimia yang terjadi tersebut membuat kapur bebas yang semula adalah mortar udara mengeras bersama air dan abu terbang yang akhirnya mempengaruhi kekuatan tekan beton. Kadar kalsium hidroksida akibat proses hidrasi yang berkurang karena adanya pengikatan yang terjadi dengan abu terbang menyebabkan porositas dan permeabilitas berkurang sehingga membuat beton menjadi lebih padat dan lebih kuat.

2. Ketahanan Beton Normal dan Beton Abu Terbang Setelah Direndam dalam Larutan Asam Sulfat Dengan Konsentrasi 2\%, 5\% dan 7\% 
Dari penelitian didapat hasil bahwa pada konsentrasi larutan asam sulfat yang sama, ternyata beton dengan bahan aditif abu terbang mempunyai ketahanan yang lebih baik dibandingkan beton normal. Untuk lebih jelasnya, hubungan antara prosentase penambahan abu terbang dengan prosentase penurunan kuat tekan beton dapat dilihat pada gambar 2.

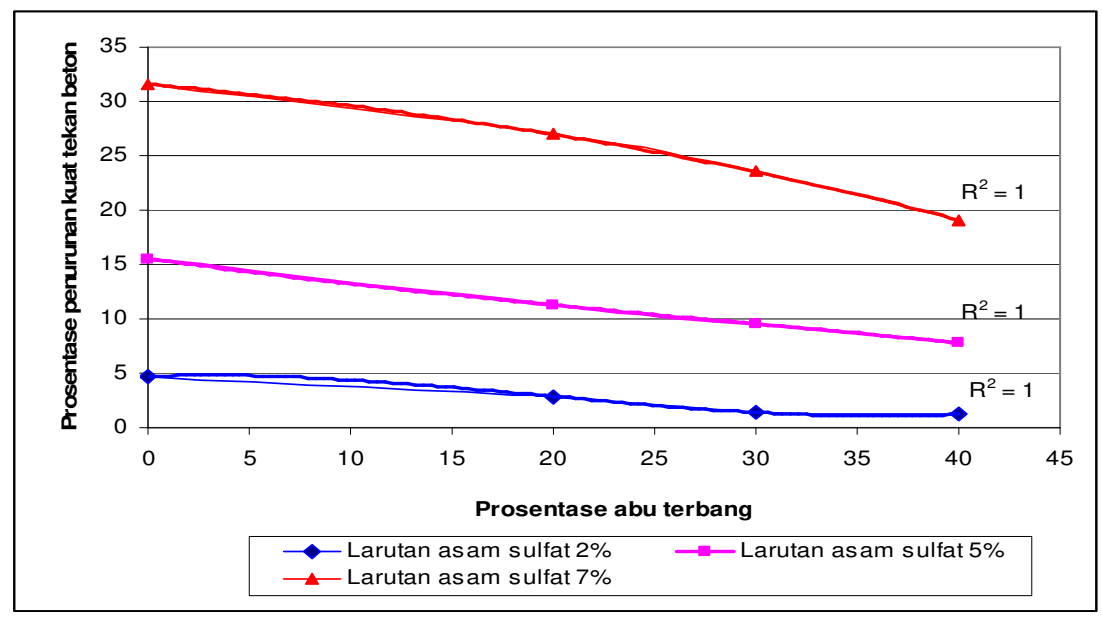

Gambar 2. Grafik hubungan prosentase abu terbang dengan prosentase penurunan kuat tekan beton

Dari Grafik 2 terlihat bahwa baik beton normal maupun beton abu terbang mengalami penurunan kuat tekan beton setelah direndam dalam larutan asam sulfat. Penurunan kuat tekan ini disebabkan karena reaksi ion-ion sulfat dengan kalsium hidroksida dan menghasilkan gypsum dan kemudian bereaksi dengan $\mathrm{C}_{3} \mathrm{~A}$ dan menghasilkan ettringite yang sifatnya lepas (loss). Dalam reaksi ini terjadi peningkatan volume yang menyebabkan terjadinya pengembangan dan pemisahan dari pasta semen yang disertai dengan tegangan-tegangan internal yang mengakibatkan retak-retak dan terlepasnya partikel-partikel beton. Hal ini akan mengurangi kepadatan beton dan pada akhirnya akan mengurangi kuat tekan beton.

Prosentase penurunan kuat tekan beton berbanding terbalik dengan prosentase penambahan abu terbang. Semakin besar prosentase abu terbang, maka semakin kecil prosentase penurunan kuat tekan beton. Hal ini disebabkan karena abu terbang bereaksi dengan kalsium hidroksida $(\mathrm{Ca}(\mathrm{OH}) 2)$ yang merupakan hasil hidrasi semen, sehingga mengurangi kadar kalsium hidroksida dalam beton. Sedangkan hal yang menyebabkan beton reaktifterhadap asam sulfat yaitu karena adanya reaksi kalsium hidroksida dengan ion-ion sulfat dan membentuk ettringite yang sifatnya lepas. Dengan berkurangnya kandungan kalsium hidroksida dalam beton karena bereaksi dengan abu terbang mengakibatkan beton abu terbang lebih tahan dilingkungan agresi sulfat dibandingkan beton normal. Selain itu abu terbang mempunyai butiran yang halus yang akan mengisi pori-pori beton, sehingga akan 
membuat beton lebih kedap air dan akan menghambat kecepatan agresi sulfat pada beton.

\section{Ketahanan Beton Abu Terbang} Dibandingkan Beton Normal Dengan Adanya Peningkatan Konsentrasi Larutan Asam Sulfat

Dari hasil penelitian dari laboratorium dapat diketahui bahwa semakin tinggi konsentrasi larutan asam sulfat, maka serangan terhadap beton juga semakin besar. Dan pada konsentrasi asam sulfat yang sama ternyata beton abu terbang mempunyai ketahanan yang lebih baik dibanding beton normal.

Untuk mengetahui seberapa jauh ketahanan beton abu terbang dibandingkan beton normal dapat dilihat pada Gambar 3 .

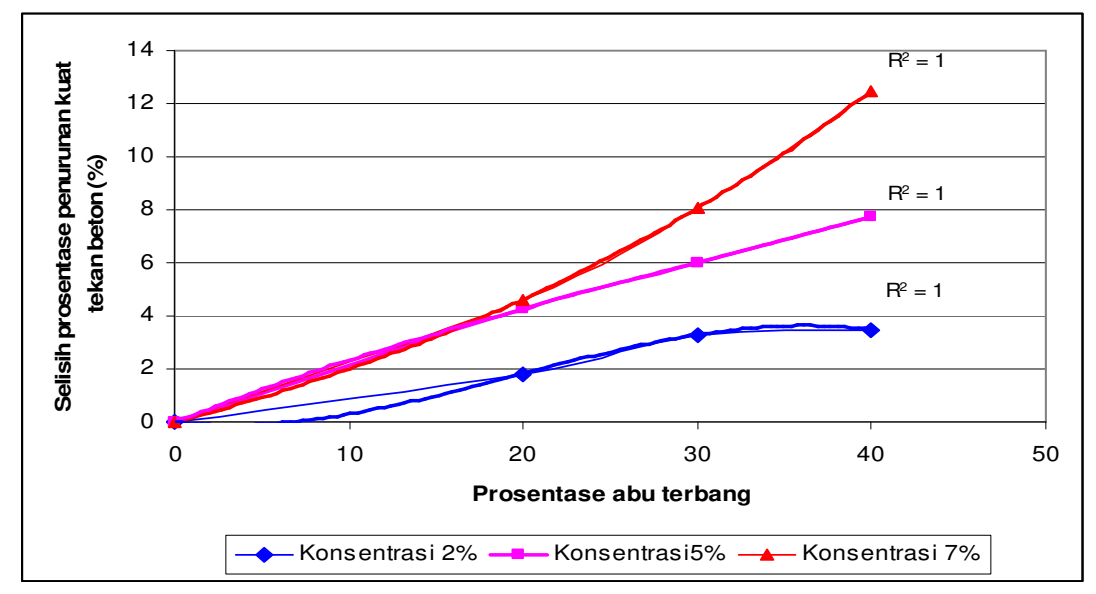

Gambar 3. Grafik hubungan prosentase abu terbang dengan selisih penurunan kuat tekan beton pada konsentrasi asam sulfat $2 \%, 5 \%, 7 \%$

Dari Gambar 3 terlihat bahwa pada beton yang direndam dalam larutan asam sulfat $2 \%$, selisih penurunan kuat tekan antara beton abu terbang dan beton normal lebih kecil dibandingkan beton yang direndam dalam larutan asam sulfat $5 \%$ dan $7 \%$. Hal ini disebabkan karena serangan sulfat pada konsentrasi $2 \%$ tidak begitu besar dan hanya terjadi pada permukaan beton, sehingga besar kecilnya pori-pori beton tidak mempunyai pengaruh besar. Sedangkan pada konsentrasi $5 \%$ dan $7 \%$, serangan sulfat tidak hanya pada permukaan tapi sudah mulai masuk kedalam beton melalui pori-pori beton. Pada beton abu terbang, pori-pori beton sebagian terisi oleh abu terbang sehingga akan menghambat serangan sulfat. Selain itu dengan penambahan abu terbang kedalam beton akan mengurangi kandungan kalsium hidroksida pada beton. Sedangkan yang menyebabkan beton reaktif terhadap larutan sulfat adalah karena adanya kalsium hidroksida dalam beton. Sehingga dengan berkurangnya kadar kalsium hidroksida dalam beton akan membuat beton tidak reaktif terhadap larutan sulfat dan pada akhirnya akan menambah ketahanan beton dalam lingkungan agresi sulfat. Dengan melihat kenyataan diatas, maka dapat disimpulkan beton dengan bahan 
aditif abu terbang lebih efektif digunakan pada larutan asam sulfat konsentrasi tinggi.

\section{KESIMPULAN}

Berdasarkan hasil penelitian tentang tinjauan penambahan aditif mineral abu terbang terhadap ketahanan beton dalam lingkungan agresi sulfat, maka dapat ditarik kesimpulan :

1. Penambahan abu terbang kedalam adukan beton dapat meningkatkan kuat tekan beton. Pada penambahan abu terbang $20 \%$, kuat tekan beton naik sebesar 23,39\%. Untuk penambahan abu terbang $30 \%$ dan $40 \%$, peningkatan kuat tekan beton masing-masing adalah $21,54 \%$ dan $0,31 \%$. Sedangkan prosentase penambahan abu terbang yang optimum yaitu sebesar 23,46\%.

2. Perendaman beton dalam larutan asam sulfat akan mengakibatkan penurunan kuat tekan beton, baik beton normal maupun beton abu terbang. Pada konsentrasi larutan asam sulfat yang sama, beton abu terbang mempunyai ketahanan yang lebih baik dibandingkan beton normal. Semakin besar prosentase abu terbang, maka semakin kecil prosentase penurunan kuat tekan beton.

3. Peningkatan konsentrasi asam sulfat akan mengakibatksn agresi yang terjadi pada beton juga semakin besar. Jika dibandingkan dengan beton normal, beton abu terbang lebih efektif bila digunakan pada larutan asam sulfat konsentrasi tinggi. Hal ini dapat dilihat dari selisih prosentase penurunan kuat tekan beton yang semakin besar dengan meningkatnya konsentrasi larutan asam sulfat.

\section{DAFTAR PUSTAKA}

American Society For Testing and Materials. 1982 . Concrete and Material Agregates (Including Manual of Agregates and Concerete Testing). ASTM. Philadelpia.

Andoyo, 2006. Pengaruh Penggunaan Abu Terbang (Fly Ash) Terhadap Kuat Tekan Dan Serapan Air Pada Mortar, Skripsi, Jurusan Teknik Sipil, Fakultas Teknik, Universitas Negeri Semarang, Semarang.

Anonim. 1989. Spesifikasi Bahan Bangunan Bagian A (Bahan Bangunan Bukan Logam), SK SNI S-04 1989- F, Departemen Pekerjaan Umum, Yayasan LPMB, Bandung.

Anonim. 2002. Tata Cara Perhitungan Struktur Beton Untuk Gedung (Beta Version) SNI 03-2847-2002, Departemen pemukiman Dan Prasarana Wilayah, Badan Penelitian Dan Pengembangan, Bandung.

Kementerian Negara Lingkungan Hidup, 2006. Fly-Bottom Ash dan Pemanfaatannya, terdapat pada http://b3.menlh.go.id/3r/article.php? article $\mathrm{id}=6$. Diakses tanggal $19 \mathrm{Mei}$ 2016. 
Murdock, L.J. \& Brook, K.M. (alih bahasa: Stephanus Hendrko). 1986. Bahan Dan Praktek Beton. Erlangga, Jakarta.

Ratmaya Urip. 2003. Teknologi Semen dan Beton: Fly Ash, Mengapa Seharusnya Dipakai pada Beton. Gresik: PT. Semen Gresik Indonesia dan PT. Varia Usaha Beton

Sudjana. 2004. Metode Statistik. Tarsito, Bandung.

Suharwanto, 2000. Penggunaan Abu Terbang (Fly Ash) dalam Beton, Prosiding Magang Intensif Beton, Pusat Antar
Universitas (PAU) Ilmu Teknik, Yogyakarta.

Tjokrodimuljo, K. 1996. Teknologi Beton, Nafiri, Yogyakarta.

Trihendradi, C. 2012. Step by Step SPSS 20 Analisis Data Statistik.Yogyakarta: C.V Andi Offset.

X. J. Song, M. Marosszeky, M. Brungs, R. Munn, 2005. Durability of fly ash based Geopolymer concrete against sulphuric acid attack, 10DBMC International Conference On Durability of Building Materials and Components, Perancis. 